\title{
STUDENTS' PERCEPTIONS ON THEIR ALMA MATER ENVIRONMENTAL SUSTAINABILITY: A COMPARATIVE STUDY IN RUSSIAN AND ARMENIAN ACADEMIC SETTINGS
}

\author{
Elena Gavrilova ${ }^{1}$, Lilit Sahakyan $^{2}$, Kira Trostina $^{3}$, Dinara Tutaeva $^{4}$
}

\begin{abstract}
Environmental sustainability is a constant concern for educational establishments as it has many vital social, academic and financial implications. The aim of this study is to investigate and compare students' perceptions regarding their university's environmental challenges in two geographically distant countries: sampling two economic universities in Russia and Armenia.

A survey related to university's environmental challenges based on 5-point Likert scale was administered to the Bachelor's and Master's students at Plekhanov Russian University of Economics (PRUE), Moscow, Russia and Yerevan Gladzor University (YGU), Yerevan, Armenia. The findings revealed that irrespective of geographical location, there are similar notable differences in students' attitudes towards understanding their own role in their university's environmental well-being. The data shows that the majority of the students strongly understand the concepts of sustainability, sustainable development, ecofriendliness and eco-tourism. The findings reveal that students' age and their education level significantly correlate with their general knowledge of sustainability. Senior students have more responsible attitude towards environmental sustainability of their university. The study established that the majority of the students perceive that environmental awareness can improve their university's facilities, quality and academic development. They understand that they themselves are fully responsible for the university's environmental welfare.

Suggestions by environmentally-conscious students in both universities were summarized in 5Ss: surveying the current state of affairs; sounding out the problems; suggesting improvements; saving university's resources; sharing the experience. The possible causes of environmental problems in the universities have been analysed and their solutions have been recommended. Including formal training in environmental studies in the curricula is suggested. It has also been advised to practice environmental ethics in the universities. The findings of the research can be used for the benefit of all stakeholders and policy makers in promoting universities' eco-conscious image, increasing students' environmental awareness and achieving substantial cost savings.
\end{abstract}

UDC Classification: 378, DOI: https://doi.org/10.12955/pss.v1.49

Keywords: sustainability, higher education, environment, PRUE, YGU.

\section{Introduction}

Scholars in different fields of studies (Economics, Management, Agriculture, Environmental science) and policy makers are concerned about issues of environmental sustainability and the effect of human behaviours on and their attitudes towards it. Many studies are considering and evaluating the consequences of humans' actions based on a long-term impact on the environmental well-being (Du Plessis et al., 2012). Since the term 'Sustainable Development' came to the global agenda in the late 1980s, governments, companies and individuals have struggled to focus on what they can do and how they can have it done, as to some extent, environmental problems concern everybody. The pursuit of sustainability has generated lifestyle changes for individuals across the globe and innovations in the fields of arts and sciences, business, education, engineering, and agriculture; historic policies and laws at municipal and state levels; and crucial international protocols and agreements. Yet the meaning of sustainability remains unsettled, and the term frequently serves as green veneer for business as usual rather than a driver of fundamental change as stated by Thiele (2016). Stern (2018) adds that without better understandings of the people involved, solutions are often hard to come by, regardless of expertise in biology, ecology, or other traditional conservation sciences. Many modern authors and researches, like Hedstrom (2018), Epstein \& Buhovac (2014), Matson et al. (2016), and Sroufe (2018) discussed sustainability transformation, strategy and governance from the angle of benefiting the organization and charting its path toward a more sustainable and profitable future.

In the last decades, increased environmental pressures throughout the world have triggered the demand for incorporating sustainability practices in both government and non-governmental educational institutions. Cavas et al., 2014; Bradley et al., 1999; Asuamah et al., 2012; Du Plessis et al., 2012; Keinonen et al., 2016, and Ozmen et al., 2015 highlighted that universities are now considered as the essential agents of change in the global economy and in the preparation of professionals, who can

\footnotetext{
${ }^{1}$ Plekhanov Russian University of Economics, Russia, Gavrilova.EA@rea.ru

${ }^{2}$ Yerevan Gladzor University, Armenia, sahakyanlilit@yahoo.com

${ }^{3}$ Plekhanov Russian University of Economics, Russia, Trostina.KV@ rea.ru, kira.v.trostina@gmail.com

${ }^{4}$ Plekhanov Russian University of Economics, Russia Tutaeva.DR@rea.ru
} 
influence the attainment of a sustainable society. Considering the fact that most corporate organizations have sustainability on their agenda, universities find themselves in a strategic position not only for research on sustainability but to produce sustainability-minded professionals as well (Ugbaja, 2018).

Universities throughout the world have to exist in the conditions of fierce competition. Thus, not only are they expected to offer varied programmes to fill any existing and emerging niches but also, they have to be keenly aware of any items on the payroll that can be optimized or costs minimized. In this connection environmental accounting which sprang on the boards' agendas in many companies has been found to deserve close attention of higher education establishments. However, despite loud public declarations about their environmental sustainability, many universities in fact neglect this aspect of their activity as the amount of costs it saved may seem insignificant in comparison of other cost-saving activities. On the one hand, literature review uncovers that a limited number of studies have explored the students' perceptions, attitudes and behaviour towards environmental sustainability in higher educational institutions (HEIs), the studies by Du Plessis et al. (2012) and Rahman et al. (2012) are among those few. In these studies, it is established that in general, respondents are worried about the environment and they are well-aware of their impact on the future of the environment. However, demographic variables affect respondent's perception, attitude and behaviour towards environmental sustainability. Age, gender, cultural, personal and professional backgrounds have influenced respondents' approaches towards sustainability, their feelings towards the environment and also their behaviour on account of "green" behaviors. On the other hand, literature study reveals that only a few higher education scholars like Emanuel \& Adams (2011) have attempted to study students' perceptions on environmental sustainability and have done it from the angle of their alma mater. This is why the importance of the present research links to current discussions regarding sustainability approaches in universities, as interpreted by Cavas et al. (2014), and goes far beyond.

\section{Rationale of the study}

The rationale for carrying out this research is related to several fundamental points. Most importantly, the purpose of the study is to shed light on the students' perception towards environmental sustainability of their university. Additionally, perception and attitudes towards understanding their own role in their university's environmental well-being have been explored. The study intends to fill the gaps identified in the literature review for such empirical work in Russia and Armenia. Moreover, the findings of the study will be discussed to identify areas of improvement.

\section{Purpose}

Russia and Armenia, being in different development stages, are faced with various environmental challenges (recycling of waste, air pollution, water and soil contamination, noise pollution, deforestation and unpredicted climate change). The present study aims at exploring the students' perception and attitude towards eco-friendliness and environmental sustainability of their universities in these two geographically remote countries. The study was conducted among the students of Plekhanov Russian University of Economics (PRUE), Moscow, Russia and Yerevan Gladzor University (YGU), Yerevan, Armenia. Students play an important role in the society as they are the future leaders, and understanding their perception of sustainable environment is important to prepare them to face future environmental challenges. The study also intends to contribute to the body of knowledge that exists in the area of sustainable development in Russia and Armenia.

The research questions are as follows: (1) What is the level of awareness among the students about environmental sustainability of the two universities under study? (2) What combination of variables (individual factors, such as age, gender, year in HEIs and academic level (Bachelor's and Master's), and motivational factors (intrinsic motivation \& extrinsic motivation) correlate best with students' perceptions of environmental policies pursued in their respective university? (3) What are the perceived barriers in increasing their university's eco-consciousness? (4) What improvements may be implemented in university's policy from the point of view of environmental accounting?

From an institutional perspective, this research is informative to a number of stakeholders including administrative staff, policy makers, environmental technicians, lecturers, researchers, students and sponsors in a particular university. It is useful for identifying key issues that can direct university's environmental policies and practices. It will also be useful to higher education governmental authorities 
in Russia and Armenia, as well as to the higher education practitioners worldwide seeking suggestions for their environmental policy.

\section{Data and Methodology}

198 survey questionnaires related to university's environmental challenges were administered to Bachelor's and Master's students (108 at PRUE, Moscow, Russia and 90 at YGU, Yerevan, Armenia). The demographic analysis revealed that $63 \%$ of the participants were Bachelor's students and $37 \%$ were Master's. Gender wise $19.7 \%$ were male students while the remaining $80.3 \%$ were female respondents. By age, $64 \%$ of the respondents were in the age group of $17-24$, and $36 \%$ belonged to $25+$ age group. Out of 198 questionnaires, 66 (33\%) were filled and processed on-line. The participants were randomly selected from various groups in the universities. The questionnaire was developed by the researchers; it was checked for validity and reliability by the universities' officials responsible for environmental sustainability.

5-point Likert-type scale was administered to the selected target group. Descriptive statistics (sample size, frequency, mean, variance and standard deviation) were used to describe the profile and distribution of the sample population (age, gender, type of institution, and academic level), and to measure the motivational factors and the perceptions of participants. Open-ended questions to gain students' perspective were also asked.

The survey was conducted in three stages. At Stage 1 (pre-study) students were asked to fill in Questionnaire 1 about their general awareness of the environmental sustainability. During Stage 2 (field observations) the participants were first asked to make some field observations in the university premises and then to fill in Questionnaire 2. At Stage 3 (after-study) some of the respondents were interviewed to make sure all the possible angles had been covered by the designed questionnaires and to grasp students' fresh outlooks. Participants were asked to brainstorm on the ways of strengthening their university's environmental sustainability, cutting costs and improving public image.

At an after-study stage the participant were invited to participate in various professionally-relevant projects and case studies during their English classes and participated in organized group discussions with their peers. The topics covered included: "Study the current state of environmental sustainability affairs in your university and prepare a report about it", "How can environmental accounting facilitate environmental awareness and result in cutting costs", "How can environmental sustainability strengthen the juridical platform of the university and help avoid possible lawsuits?", "How can environmental friendliness improve the university's public image and increase its local and international profile?", etc.

Despite the fact that there are many scientifically-proven methods to assess an educational institution's environmental sustainability, understanding it from its students' point of view has many advantages as compared to the other stakeholders. Students populace is much larger than that of any other stakeholders in the university; they are the biggest polluters in the campus as they are the ones who use most of the resources of their university; students have wider access to different areas of their university premises than any particular teacher, who is mostly tied up to the particular department. In comparison to the teaching staff, who have been working there for many years and are accustomed to the changes which take place, students come from geographically diverse educational establishments and have a fresh outlook on the current state of affairs at their new alma mater. Moreover, students are more unbiased in their responses as the question of environmental responsibility has no direct impact on or connections to the learning process. They are likely to be more creative and knowledgeable in the areas of finance and law and thus are able to look at university's environmental blunders and misconduct from the professional point of view, e.g. possible lawsuits or financial losses. This results of the study from two geographically remote areas let researchers make some generalizations. The study was conducted for the future generation with the aim of enhancing students' environmental consciousness and ensuring further sustainable development of Russian and Armenian societies and communities, thus leading students to act as 'green-role-models' for future generations.

\section{Results and Discussion}

The survey results were summarized in four tables, Table 1 and 2 display students' general knowledge of sustainability and their perceptions and assessments of the university's sustainability are shown in Table 3 and 4. 


\begin{tabular}{|l|l|c|c|c|c|c|}
\hline \multicolumn{2}{|l|}{ Table 1: Students' general knowledge of sustainability } \\
\hline & $\begin{array}{c}\mathbf{5 f} \\
\mathbf{\%}\end{array}$ & $\begin{array}{c}\mathbf{4 f} \\
\mathbf{\%}\end{array}$ & $\begin{array}{c}\mathbf{3 f} \\
\mathbf{\%}\end{array}$ & $\begin{array}{c}\mathbf{2 ~ f} \\
\mathbf{\%}\end{array}$ & $\begin{array}{c}\mathbf{1 ~ f} \\
\mathbf{\%}\end{array}$ \\
\hline Variables & 138 & 39 & 15 & 6 & 0 \\
& $69.7 \%$ & $19.6 \%$ & $7.6 \%$ & $3.1 \%$ & $0 \%$ \\
\hline 1. What is SUSTAINABILITY? & 117 & 36 & 33 & 12 & 0 \\
& $59.1 \%$ & $18.2 \%$ & $16.7 \%$ & $6 \%$ & $0 \%$ \\
\hline DEVELOPMENT? & 165 & 12 & 9 & 12 & 0 \\
\hline 3. What is ECO-FRIENDLY? & $83.4 \%$ & $6 \%$ & $4.6 \%$ & $6 \%$ & $0 \%$ \\
\hline 4. What is ECO-TOURISM? & 141 & 39 & 6 & 6 & 6 \\
& $71 \%$ & $19.7 \%$ & $3.1 \%$ & $3.1 \%$ & $3.1 \%$ \\
\hline 5. What is ECO-TAX? & 87 & 51 & 21 & 33 & 6 \\
& $43.8 \%$ & $25.8 \%$ & $10.6 \%$ & $16.7 \%$ & $3.1 \%$ \\
\hline 6. What is GREEN & 75 & 39 & 42 & 42 & 0 \\
ACCOUNTING? & $37.9 \%$ & $19.7 \%$ & $21.2 \%$ & $21.2 \%$ & $0 \%$ \\
\hline
\end{tabular}

Keys: $5=\mathrm{I}$ know what it is, $4=\mathrm{I}$ am not sure I understand what it is, $3=\mathrm{I}$ do not know what it is, $2=\mathrm{I}$ have never heard about it, $1=$ I do not care at all.

Source: Authors

Table 1 shows the respondents' general knowledge about the sustainability issues. The results show that the majority of the respondents strongly understand the concepts of sustainability (69.7\%), sustainable development $(59.1 \%)$, eco-friendliness $(83.4 \%)$ and eco-tourism (71\%). However, $30.4 \%$ of the respondents either do not know, have never heard or even do not care at all about the issues of eco-tax. Similarly, 42.4\% accept their unawareness about green accounting concept.

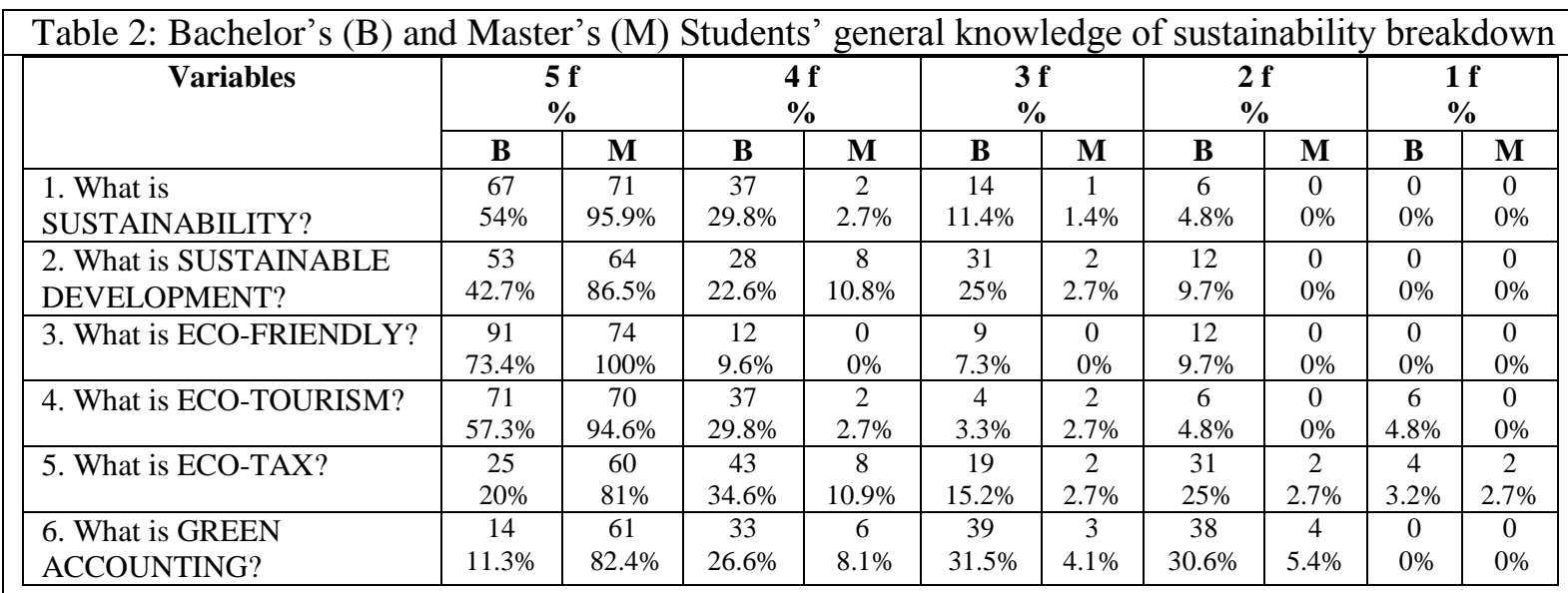

Keys: $5=\mathrm{I}$ know what it is, $4=\mathrm{I}$ am not sure I understand what it is, $3=\mathrm{I}$ do not know what it is, $2=\mathrm{I}$ have never heard about it, $1=$ I do not care at all.

Source: Authors

Table 2 shows degree wise students' general knowledge about sustainability. The results showed that the respondents' awareness level of sustainability issues generally rises with the years of studies in higher education, as $100 \%$ of Master's students understand the concept of eco-friendliness as opposed to $73.4 \%$ of bachelor's students. Notably (however), there is a significant gap between Bachelor's and Master's students' understanding of more complex issues of sustainability. The percentage of Master's students having strong understanding of eco-tax quadrupled the number of Bachelor's students $(81 \%$ and $20 \%$ respectively) and the difference is even wider in understanding the concept of green accounting. Whereas only $11.3 \%$ of Bachelor's students know what it is, the overwhelming majority of Master's students (82.4\%) admit that they fully understand its meaning. In summary, it can be deduced that the students' general knowledge of sustainability issues increases with the level of education.

Table 3 summarizes students' perceptions and assessments of the university's sustainability based on their field observations in their respective university. The data reveals that the majority of students agree that environmental awareness can improve the quality of university's facilities and contribute to the academic development (84.8\%). They believe that they themselves are fully responsible for the university's environmental well-being (77.4\%). However, only half of the respondents (51.5\%) are sure that their university is adept of environmental sustainability and highlight such areas of concern as 
separate collection of waste and garbage (only $13.6 \%$ agree, whereas $56.1 \%$ are undecided), the use of energy-saving electric bulbs in the classrooms (10.6\% agree as opposed to $42.4 \%$ who are undecided), malfunctioning taps with dripping water in the sanitary rooms $(24.2 \%)$ and others. Furthermore, only $12.1 \%$ of the respondents stated that from 80 to $100 \%$ of their academic assignments are checked by their lecturers and professors on-line, whereas almost the same number (13.6\%) revealed that less than $10 \%$ of their work is processed in an electronic format.

\begin{tabular}{|c|c|c|c|c|c|}
\hline Variables & $\begin{array}{l}\mathbf{5 f} \\
\%\end{array}$ & $\begin{array}{l}\mathbf{4 f} \\
\%\end{array}$ & $\begin{array}{l}3 \mathbf{3 f} \\
\%\end{array}$ & $\begin{array}{l}2 \mathbf{f} \\
\%\end{array}$ & $\begin{array}{l}1 \mathrm{f} \\
\%\end{array}$ \\
\hline $\begin{array}{l}\text { 1. I am sure that my university is an adept (keen } \\
\text { follower) of environmental sustainability }\end{array}$ & $\begin{array}{c}24 \\
12.1 \%\end{array}$ & $\begin{array}{c}78 \\
39.4 \%\end{array}$ & $\begin{array}{c}66 \\
33.3 \%\end{array}$ & $\begin{array}{c}27 \\
13.6 \%\end{array}$ & $\begin{array}{c}3 \\
1.6 \%\end{array}$ \\
\hline $\begin{array}{l}\text { 2. I agree that environmental awareness can improve } \\
\text { quality of university's facilities and academic } \\
\text { development }\end{array}$ & $\begin{array}{c}84 \\
42.4 \%\end{array}$ & $\begin{array}{c}84 \\
42.4 \%\end{array}$ & $\begin{array}{c}24 \\
12.1 \%\end{array}$ & $\begin{array}{c}6 \\
3.1 \%\end{array}$ & $0 \%$ \\
\hline $\begin{array}{l}\text { 3. I feel that alongside with my co-students I am fully } \\
\text { responsible for the university's environmental well- } \\
\text { being }\end{array}$ & $\begin{array}{c}63 \\
31.8 \%\end{array}$ & $\begin{array}{c}90 \\
45.4 \%\end{array}$ & $\begin{array}{c}42 \\
21.2 \%\end{array}$ & $\begin{array}{c}3 \\
1.6 \%\end{array}$ & $\begin{array}{c}0 \\
0 \%\end{array}$ \\
\hline $\begin{array}{l}\text { 4. I can do very little to save the environment while I } \\
\text { am inside my university's premises }\end{array}$ & $\begin{array}{c}21 \\
10.6 \% \\
\end{array}$ & $\begin{array}{c}33 \\
16.7 \% \\
\end{array}$ & $\begin{array}{c}27 \\
13.6 \% \\
\end{array}$ & $\begin{array}{c}75 \\
37.9 \% \\
\end{array}$ & $\begin{array}{c}42 \\
21.2 \% \\
\end{array}$ \\
\hline $\begin{array}{l}\text { 5. It doesn't concern me in any way and I don't care } \\
\text { about the university's environmental sustainability at all }\end{array}$ & $\begin{array}{c}3 \\
1.6 \% \\
\end{array}$ & $\begin{array}{c}0 \\
0 \% \\
0 \%\end{array}$ & $\begin{array}{c}24 \\
12.1 \% \\
\end{array}$ & $\begin{array}{c}84 \\
42.4 \% \\
\end{array}$ & $\begin{array}{c}87 \\
43.9 \% \\
\end{array}$ \\
\hline $\begin{array}{l}\text { 6. Do you know if there is "Environment } \\
\text { Sustainability" section on the university's website? }\end{array}$ & $\begin{array}{c}9 \\
4.6 \%\end{array}$ & $\begin{array}{c}108 \\
54.4 \%\end{array}$ & $\begin{array}{c}72 \\
36.4 \%\end{array}$ & $\begin{array}{c}9 \\
4.6 \%\end{array}$ & $\begin{array}{c}0 \\
0 \%\end{array}$ \\
\hline $\begin{array}{l}\text { 7. Are you aware of means of participation in the } \\
\text { context of environmental management initiatives in } \\
\text { your university? }\end{array}$ & $\begin{array}{c}75 \\
37.9 \%\end{array}$ & $\begin{array}{c}75 \\
37.9 \%\end{array}$ & $\begin{array}{c}39 \\
19.6 \%\end{array}$ & $\begin{array}{c}9 \\
4.6 \%\end{array}$ & $\begin{array}{l}0 \\
0 \%\end{array}$ \\
\hline $\begin{array}{l}\text { 8. Are there any special trainings sessions for students } \\
\text { to enhance their understanding and importance of } \\
\text { environmental sustainability? }\end{array}$ & $\begin{array}{c}57 \\
28.8 \%\end{array}$ & $\begin{array}{c}120 \\
60.5 \%\end{array}$ & $\begin{array}{c}15 \\
7.6 \%\end{array}$ & $\begin{array}{c}6 \\
3.1 \%\end{array}$ & $\begin{array}{c}0 \\
0 \%\end{array}$ \\
\hline $\begin{array}{l}\text { 9. Are different categories of waste and garbage } \\
\text { collected separately in all universities' premises? }\end{array}$ & $\begin{array}{c}27 \\
13.6 \% \\
\end{array}$ & $\begin{array}{c}54 \\
27.3 \% \\
\end{array}$ & $\begin{array}{c}111 \\
56.1 \% \\
\end{array}$ & $\begin{array}{c}6 \\
3.1 \% \\
\end{array}$ & $\begin{array}{c}0 \\
0 \%\end{array}$ \\
\hline $\begin{array}{l}\text { 10. Are energy-saving electric bulbs used in all } \\
\text { classrooms, corridors and other premises? }\end{array}$ & $\begin{array}{c}21 \\
10.6 \%\end{array}$ & $\begin{array}{c}93 \\
47 \% \\
\end{array}$ & $\begin{array}{c}84 \\
42.4 \% \\
\end{array}$ & $\begin{array}{c}0 \\
0 \%\end{array}$ & $\begin{array}{c}0 \\
0 \%\end{array}$ \\
\hline $\begin{array}{l}\text { 11. Do the lights automatically switch off when there is } \\
\text { nobody in the classroom? }\end{array}$ & $\begin{array}{c}9 \\
4.6 \%\end{array}$ & $\begin{array}{l}12 \\
6 \%\end{array}$ & $\begin{array}{c}177 \\
89.4 \%\end{array}$ & $\begin{array}{c}0 \\
0 \%\end{array}$ & $\begin{array}{c}0 \\
0 \%\end{array}$ \\
\hline $\begin{array}{l}\text { 12. Have you ever noticed malfunctioning taps with } \\
\text { dripping water in the sanitary rooms? }\end{array}$ & $\begin{array}{c}48 \\
24.2 \% \\
\end{array}$ & $\begin{array}{c}45 \\
22.7 \% \\
\end{array}$ & $\begin{array}{c}99 \\
50 \% \\
\end{array}$ & $\begin{array}{c}6 \\
3.1 \% \\
\end{array}$ & $\begin{array}{c}0 \\
0 \%\end{array}$ \\
\hline $\begin{array}{l}\text { 13. Are too many chemicals used by environmental } \\
\text { technicians while cleaning the premises? }\end{array}$ & $\begin{array}{c}30 \\
15.2 \% \\
\end{array}$ & $\begin{array}{c}129 \\
65.2 \%\end{array}$ & $\begin{array}{c}30 \\
15.2 \% \\
\end{array}$ & $\begin{array}{c}9 \\
4.6 \% \\
\end{array}$ & $\begin{array}{c}0 \\
0 \%\end{array}$ \\
\hline $\begin{array}{l}\text { 14. What is the percentage of your academic } \\
\text { assignments checked by your lecturers and professors } \\
\text { on-line? }\end{array}$ & $\begin{array}{c}24 \\
12.1 \%\end{array}$ & $\begin{array}{c}42 \\
21.2 \%\end{array}$ & $\begin{array}{c}48 \\
24.2 \%\end{array}$ & $\begin{array}{c}57 \\
28.8 \%\end{array}$ & $\begin{array}{c}27 \\
13.6 \%\end{array}$ \\
\hline $\begin{array}{l}\text { 15. When you take-away some snacks from the } \\
\text { universities catering premises how often are they made } \\
\text { from recyclable materials? }\end{array}$ & $\begin{array}{l}12 \\
6 \%\end{array}$ & $\begin{array}{c}33 \\
16.7 \%\end{array}$ & $\begin{array}{c}90 \\
45.5 \%\end{array}$ & $\begin{array}{c}48 \\
24.2 \%\end{array}$ & $\begin{array}{c}15 \\
7.6 \%\end{array}$ \\
\hline
\end{tabular}

Keys to Questions 1 to 5: 5= strongly agree, 4=Agree, 3= undecided, 2= Disagree, $1=$ strongly disagree

Keys to Questions 6 to $13: 5=$ Yes, $4=$ not sure, $3=$ no, $2=I$ do not care, $1=$ no one cares

Keys to Question 14: 5-80-100\%, 4- $41-80 \%$, 3- $21-50 \%, 2-11-20 \%, 1-0-10 \%$

Keys to Questions 15: 5 - always, 4- very often, 3- sometimes, 2- seldom, 1- never

Source: Authors

Table 4 summarizes students' perceptions and assessments of the university's sustainability in terms of their age. For the purpose of the study, the responses were classified into two groups, namely junior group (64\%) and senior group (36\%). Junior group comprises of bachelor's students in the age group of 17-24 years while senior group comprises of master's students in the age group of 25 years and above. In general, the study established that as compared to junior group, students in the senior group have more responsible attitude towards environmental sustainability of their university. $91 \%$ of senior student 
fully accepted their joint responsibility for the university's environmental well-being, while only $70.2 \%$ of their junior counterparts took responsibility towards the issue. Besides, $68.7 \%$ of senior respondents were aware of means of participation in the context of environmental management initiatives in their university which exceeded the number of junior students' awareness $(22.1 \%)$ by three times. Significantly, the percentage of online assessment of academic assignments of Master's students is more than that of bachelor's students, as only $9.2 \%$ of junior respondents submit 80 to $100 \%$ of their assignments in various e-formats, in comparison to $17.9 \%$ senior students.

Table 4: Students' perceptions and assessments of the university's sustainability (based on students' field observations)

\begin{tabular}{|c|c|c|c|c|c|c|c|c|c|c|}
\hline \multirow[t]{2}{*}{ Variables } & \multicolumn{2}{|c|}{$\begin{array}{c}5 \text { f } \\
\%\end{array}$} & \multicolumn{2}{|c|}{$\begin{array}{c}\mathbf{4 f} \\
\%\end{array}$} & \multicolumn{2}{|c|}{$\begin{array}{c}\mathbf{3 f} \\
\%\end{array}$} & \multicolumn{2}{|c|}{$\begin{array}{l}2 \text { f } \\
\%\end{array}$} & \multicolumn{2}{|c|}{$\begin{array}{l}\mathbf{1 f} \\
\%\end{array}$} \\
\hline & $\mathrm{J}$ & $\mathrm{S}$ & $\mathrm{J}$ & $\mathrm{S}$ & $\mathrm{J}$ & $\mathrm{S}$ & $\mathrm{J}$ & $\mathrm{S}$ & $\mathrm{J}$ & $\mathrm{S}$ \\
\hline $\begin{array}{l}\text { 1. I am sure that my university is an } \\
\text { adept (keen follower) of environmental } \\
\text { sustainability }\end{array}$ & $\begin{array}{c}18 \\
13.7 \%\end{array}$ & $\begin{array}{l}6 \\
9 \%\end{array}$ & $\begin{array}{c}42 \\
32.1 \%\end{array}$ & $\begin{array}{c}36 \\
53.7 \%\end{array}$ & $\begin{array}{c}42 \\
32.1 \%\end{array}$ & $\begin{array}{c}24 \\
35.8 \%\end{array}$ & $\begin{array}{c}26 \\
19.8 \%\end{array}$ & $1.5 \%$ & $\begin{array}{c}3 \\
2.3 \%\end{array}$ & $0 \%$ \\
\hline $\begin{array}{l}\text { 2. I agree that environmental awareness } \\
\text { can improve quality of university's } \\
\text { facilities and academic development }\end{array}$ & $\begin{array}{r}52 \\
39.7 \% \\
\end{array}$ & $\begin{array}{r}32 \\
47.7 \% \\
\end{array}$ & $\begin{array}{r}56 \\
42.8 \% \\
\end{array}$ & $\begin{array}{r}28 \\
41.8 \% \\
\end{array}$ & $\begin{array}{c}18 \\
13.7 \% \\
\end{array}$ & 6 & $\begin{array}{c}5 \\
3.8 \% \\
\end{array}$ & $\begin{array}{c}1 \\
1.5 \% \\
\end{array}$ & $0 \%$ & $0 \%$ \\
\hline $\begin{array}{l}\text { 3. I feel that alongside with my co- } \\
\text { students I am fully responsible for the } \\
\text { university's environmental well-being }\end{array}$ & $\begin{array}{c}30 \\
22.9 \% \\
\end{array}$ & $\begin{array}{c}33 \\
49.2 \% \\
\end{array}$ & $\begin{array}{c}62 \\
47.3 \% \\
\end{array}$ & $\begin{array}{c}28 \\
41.8 \% \\
\end{array}$ & $\begin{array}{c}36 \\
27.5 \% \\
\end{array}$ & $\begin{array}{l}6 \\
9 \%\end{array}$ & $\begin{array}{c}3 \\
2.3 \% \\
\end{array}$ & $0 \%$ & $0 \%$ & $0 \%$ \\
\hline $\begin{array}{l}\text { 4. I can do very little to save the } \\
\text { environment while I am inside my } \\
\text { university's premises }\end{array}$ & $\begin{array}{c}6 \\
4.5 \% \\
\end{array}$ & $\begin{array}{c}15 \\
22.4 \% \\
\end{array}$ & $\begin{array}{c}20 \\
15.3 \% \\
\end{array}$ & $\begin{array}{c}13 \\
19.4 \%\end{array}$ & $\begin{array}{c}20 \\
15.3 \%\end{array}$ & $\begin{array}{c}7 \\
10.5 \% \\
\end{array}$ & $\begin{array}{c}53 \\
40.5 \%\end{array}$ & $\begin{array}{c}22 \\
32.8 \% \\
\end{array}$ & $\begin{array}{c}32 \\
24.4 \%\end{array}$ & $\begin{array}{c}10 \\
14.9 \%\end{array}$ \\
\hline $\begin{array}{l}\text { 5. It doesn't concern me in any way and } \\
\text { I don't care about the university's } \\
\text { environmental sustainability at all }\end{array}$ & $\begin{array}{c}3 \\
2.3 \% \\
\end{array}$ & $0 \%$ & $\begin{array}{l}0 \\
0 \% \\
\end{array}$ & $0 \%$ & 17 & $\begin{array}{c}7 \\
10.5 \% \\
\end{array}$ & 55 & $\begin{array}{c}29 \\
43.3 \% \\
\end{array}$ & $\begin{array}{c}56 \\
42.7 \% \\
\end{array}$ & $\begin{array}{c}31 \\
46.2 \% \\
\end{array}$ \\
\hline $\begin{array}{l}\text { 6. Do you know if there is } \\
\text { "Environment Sustainability" section } \\
\text { on the university's website? }\end{array}$ & $\begin{array}{c}2 \\
1.5 \%\end{array}$ & $\begin{array}{c}7 \\
10.5 \% \\
\end{array}$ & $\begin{array}{l}72 \\
55 \%\end{array}$ & $\begin{array}{c}36 \\
53.7 \% \\
\end{array}$ & $\begin{array}{c}50 \\
38.2 \% \\
\end{array}$ & $\begin{array}{c}22 \\
32.8 \% \\
\end{array}$ & $\begin{array}{c}7 \\
5.3 \% \\
\end{array}$ & $3 \%$ & 0 & $0 \%$ \\
\hline $\begin{array}{l}\text { 7. Are you aware of means of } \\
\text { participation in the context of } \\
\text { environmental management initiatives } \\
\text { in your university? }\end{array}$ & $\begin{array}{c}29 \\
22.1 \%\end{array}$ & $\begin{array}{c}46 \\
68.7 \%\end{array}$ & $\begin{array}{c}64 \\
48.9 \%\end{array}$ & $\begin{array}{c}11 \\
16.4 \%\end{array}$ & $\begin{array}{c}30 \\
22.9 \%\end{array}$ & $\begin{array}{c}9 \\
13.4 \%\end{array}$ & $\begin{array}{c}8 \\
6.1 \%\end{array}$ & $\begin{array}{c}1 \\
1.5 \%\end{array}$ & $0 \%$ & $0 \%$ \\
\hline $\begin{array}{l}\text { 8. Are there any special trainings } \\
\text { sessions for students to enhance their } \\
\text { understanding and importance of } \\
\text { environmental sustainability? }\end{array}$ & $\begin{array}{c}33 \\
25.2 \%\end{array}$ & $\begin{array}{c}24 \\
35.8 \%\end{array}$ & $\begin{array}{c}88 \\
67.2 \%\end{array}$ & $\begin{array}{c}32 \\
47.8 \%\end{array}$ & $\begin{array}{c}5 \\
3.8 \%\end{array}$ & $\begin{array}{c}10 \\
14.9 \%\end{array}$ & $\begin{array}{c}5 \\
3.8 \%\end{array}$ & $\begin{array}{c}1 \\
1.5 \%\end{array}$ & $\%$ & $0 \%$ \\
\hline $\begin{array}{l}\text { 9. Are different categories of waste and } \\
\text { garbage collected separately in all } \\
\text { universities' premises? }\end{array}$ & 17 & $\begin{array}{c}10 \\
14.9 \% \\
\end{array}$ & $\begin{array}{r}39 \\
29.8 \% \\
\end{array}$ & $\begin{array}{c}15 \\
22.4 \% \\
\end{array}$ & $\begin{array}{c}70 \\
53.4 \% \\
\end{array}$ & $\begin{array}{r}41 \\
61.2 \% \\
\end{array}$ & $\begin{array}{c}5 \\
3.8 \% \\
\end{array}$ & $\begin{array}{c}1 \\
1.5 \% \\
\end{array}$ & $0 \%$ & $0 \%$ \\
\hline $\begin{array}{l}\text { 10. Are energy-saving electric bulbs } \\
\text { used in all classrooms, corridors and } \\
\text { other premises? }\end{array}$ & $\begin{array}{c}15 \\
11.4 \%\end{array}$ & $\begin{array}{l}6 \\
9 \%\end{array}$ & $\begin{array}{c}58 \\
44.3 \%\end{array}$ & $\begin{array}{c}35 \\
52.2 \%\end{array}$ & $\begin{array}{c}58 \\
44.3 \%\end{array}$ & $\begin{array}{c}26 \\
38.8 \% \\
\end{array}$ & $0 \%$ & $0 \%$ & $0 \%$ & $0 \%$ \\
\hline $\begin{array}{l}\text { 11. Do the lights automatically switch } \\
\text { off when there is nobody in the } \\
\text { classroom? }\end{array}$ & $\begin{array}{c}6 \\
4.6 \% \\
\end{array}$ & $\begin{array}{c}3 \\
4.5 \% \\
\end{array}$ & $\begin{array}{c}10 \\
7.6 \% \\
\end{array}$ & $3 \%$ & $\begin{array}{c}115 \\
87.8 \% \\
\end{array}$ & $\begin{array}{c}62 \\
92.5 \% \\
\end{array}$ & $\begin{array}{l}0 \\
0 \% \\
\end{array}$ & $\begin{array}{l}0 \\
0 \% \\
\end{array}$ & $0 \%$ & $0 \%$ \\
\hline $\begin{array}{l}\text { 12. Have you ever noticed } \\
\text { malfunctioning taps with dripping } \\
\text { water in the sanitary rooms? }\end{array}$ & $\begin{array}{c}24 \\
18.3 \% \\
\end{array}$ & $\begin{array}{c}24 \\
35.8 \% \\
\end{array}$ & $\begin{array}{c}28 \\
21.4 \% \\
\end{array}$ & $\begin{array}{c}17 \\
25.3 \% \\
\end{array}$ & $\begin{array}{l}76 \\
58 \% \\
\end{array}$ & $\begin{array}{c}23 \\
34.2 \% \\
\end{array}$ & $\begin{array}{c}3 \\
2.3 \%\end{array}$ & $\begin{array}{c}3 \\
4.5 \% \\
\end{array}$ & $0 \%$ & $0 \%$ \\
\hline $\begin{array}{l}\text { 13. Are too many chemicals used by } \\
\text { environmental technicians while } \\
\text { cleaning the premises? }\end{array}$ & $\begin{array}{c}13 \\
9.9 \% \\
\end{array}$ & $\begin{array}{r}17 \\
25.3 \% \\
\end{array}$ & $\begin{array}{r}89 \\
67.9 \% \\
\end{array}$ & $\begin{array}{c}40 \\
59.7 \% \\
\end{array}$ & $\begin{array}{c}25 \\
19.1 \% \\
\end{array}$ & $\begin{array}{c}5 \\
7.5 \% \\
\end{array}$ & $\begin{array}{c}4 \\
3.1 \% \\
\end{array}$ & $\begin{array}{c}5 \\
7.5 \% \\
\end{array}$ & $0 \%$ & $0 \%$ \\
\hline $\begin{array}{l}\text { 14. What is the percentage of your } \\
\text { academic assignments checked by your } \\
\text { lecturers and professors on-line? }\end{array}$ & $\begin{array}{c}12 \\
9.2 \%\end{array}$ & $\begin{array}{c}12 \\
17.9 \%\end{array}$ & $\begin{array}{c}29 \\
22.1 \%\end{array}$ & $\begin{array}{c}13 \\
19.4 \%\end{array}$ & $\begin{array}{c}33 \\
25.2 \%\end{array}$ & $\begin{array}{c}15 \\
22.4 \% \\
\end{array}$ & $\begin{array}{c}37 \\
28.2 \%\end{array}$ & $\begin{array}{c}20 \\
29.8 \%\end{array}$ & $\begin{array}{c}20 \\
15.3 \%\end{array}$ & $\begin{array}{c}7 \\
10.5 \%\end{array}$ \\
\hline $\begin{array}{l}\text { 16. When you take-away some snacks } \\
\text { from the universities catering premises } \\
\text { how often are they made from } \\
\text { recyclable materials? }\end{array}$ & $\begin{array}{c}4 \\
3.1 \%\end{array}$ & $\begin{array}{c}8 \\
11.9 \%\end{array}$ & $\begin{array}{c}22 \\
16.8 \%\end{array}$ & $6.4 \%$ & $\begin{array}{c}60 \\
45.8 \%\end{array}$ & $\begin{array}{c}30 \\
44.8 \%\end{array}$ & $\begin{array}{c}34 \\
25.9 \%\end{array}$ & $\begin{array}{c}14 \\
20.9 \%\end{array}$ & $\begin{array}{c}11 \\
8.4 \%\end{array}$ & $6 \%$ \\
\hline
\end{tabular}

Keys to Questions 1 to 5: 5= strongly agree, 4=Agree, $3=$ undecided, $2=$ Disagree, $1=$ strongly disagree

Keys to Questions 6 to 13: $5=$ Yes, $4=$ not sure, $3=$ no, $2=\mathrm{I}$ do not care, $1=$ no one cares

Keys to Question 14: 5-80-100\%, 4- $41-80 \%, 3-21-50 \%, 2-11-20 \%, 1-0-10 \%$

Keys to Questions 15: 5 - always, 4- very often, 3- sometimes, 2- seldom, 1- never

Source: Authors 
In summary, the study revealed that demographic variables (age, year of studies in HEI) affect respondent's perception, attitude and behaviour towards their Alma Mater's environmental sustainability. The study established that in general senior students have more earnestness and seriousness towards environmental issues than junior students.

\section{Conclusion}

The study found that respondents in the given Russian and Armenian universities have varied opinions on the environmental sustainability and their own role in the process. Respondents' sex, age and year in HEIs influenced their perception of environment sustainability. Research concluded that perceptions of students in both Russian and Armenia ranged from accepting full responsibility towards environment sustainability to complete neglect towards it.

The results of the study offer key implications to the university's policy-makers. The paper helps in assessing the percentage of students negligent and indifferent about environment sustainability. It will serve as a signal whether or not a formal training in environmental studies should be included in the curricular. The results may also help in identifying areas of particular concern which were probably missed out by the officials responsible for it. Best projects by the students on environmental accounting may also be implemented into the university's overall financial strategy. Publicizing of the results may induce other universities to benchmark their environmental sustainability against other similar higher education establishments, and thus, contribute to the spread of scientific knowledge on environmental topics and its further development.

Exploring the concept and practice of sustainability through a broad range of current issues and debates, special attention should be paid to the importance of local relationships and responsibilities. Special focus should be made on incremental measures that may prove beneficial in furthering this mission. Promoting environmental sustainability within universities presents a hopeful account of crucial opportunities and a valuable resource for students as well as general readers keen to grapple with one of the most pressing issues of contemporary times.

As a result of the study conducted at PRUE and YGU, it was established that students have positive perception of their Alma Mater's Environmental Sustainability. They are also willing to uphold sustainable environment in their community and ensure acting as 'green-role-models' for future generations. However, there are some obstacles to deal with, namely, the lack of strong attitude of strategic entities towards environmental sustainability, as well as insufficient initiation and low participation by students in eco-projects. From the qualitative interviews with the students of PRUE and YGU, it emerged that the level of efficiency of the Alma Mater environmental management at the universities is primarily connected with institutional trust towards key entities and the level of students' active participation in environmental management initiated by the university authorities, teaching staff and student union in relation to formal social networks and social trust. Moreover, during the personal interviews the initial reaction of the students at YGU was that for the effective management of environmental sustainability, all the strategic entities (the RA Government, the Ministry of Nature Protection of Armenia, the Ministry of Education and Science of the Republic of Armenia, and Yerevan Gladzor University Rectorate) should have a more serious and responsible attitude towards it. Other important factors guaranteeing high level of environmental sustainability in academic settings, suggested by YGU students, included the significance of institutional trust towards these key bodies as responsible actors and targeted action plans of cooperation designed by those responsible actors (including students, professors, university administration and student union) collaboratively. Another major finding of the qualitative interviews carried out at YGU is the low level of cooperation from all key entities in their academic community and the lack of environmental initiatives. Subsequently, all these issues are highly linked to level of awareness and participation of students in the effective management of environmental sustainability. In sum, to enhance the eco-conscious image of both universities some proactive measures should be taken (1) to build social trust towards the stakeholders and policy makers, (2) to amend the system of cooperation between the key entities to target possible variables in providing policies to address environmental issues, (3) to design extra-curricular modules to increase students' motivation and active participation in management of their Alma Mater's environmental sustainability and subsequently, (4) to educate environmentally-conscious students for the sake of mutual benefits and (5) finally, to endorse the university's eco-conscious image. 


\section{References}

Asuamah, S. Y., Felix, A. T., \& Darkwa, B. (2012). What is the perception of students towards environmental sustainability. Journal of Natural Sciences Research, 2(10), 114-122.

Bradley, J. C., Waliczek, T. M., \& Zajicek, J. M. (1999). Relationship between environmental knowledge and environmental attitude of high school students. The Journal of Environmental Education, 30(3), 17-21. https://doi.org/10.1080/00958969909601873

Cavas, B., Ertepinar, H., \& Teksoz, G. (2014). Sustainability in schools of education in Turkey: In the words of Lecturers. Journal of Baltic Science Education, 13(4), 469-482.

Du Plessis, A. J., Nel, P. S., \& Al-Shamaa, S. (2012). The perceptions of tertiary students towards environmental sustainability: some empirical evidence from a longitudinal study. World Review of Business Research, 2(3), 43-62.

Emanuel, R., \& Adams, J. N. (2011). College students' perceptions of campus sustainability. International Journal of Sustainability in Higher Education, 12(1), 79-92. https://doi.org/10.1108/14676371111098320

Epstein, M. J., \& Buhovac, A. R. (2014). Making sustainability work: Best practices in managing and measuring corporate social, environmental, and economic impacts. Berrett-Koehler Publishers.

Hedstrom, G. S. (2018). Sustainability: What it is and how to Measure it. Walter de Gruyter GmbH \& Co KG.

Keinonen, T., Palmberg, I., Kukkonen, J., Yli-Panula, E., Persson, C., \& Vilkonis, R. (2016). Higher education students' perceptions of environmental issues and media coverage. Discourse and communication for sustainable education, 7(1), 5-22. https://doi.org/10.1515/dcse-2016-0001

Matson, P., Clark, W. C., \& Andersson, K. (2016). Pursuing sustainability: a guide to the science and practice. Princeton University Press.

Ozmen, D., Cakmakc1-Cetinkaya, A., Nehir, S. (2005). University students' attitudes towards environmental problems. TAF Preventive Medicine Bulletin, 4(6), 330-344.

Rahman, N., Chen, J., \& Toh, W. (2012). Environmental sustainability: perceptions of international students in New Zealand. Asia Pacific Journal of Business and Management, 3(1), 1-11.

Sroufe, R. P. (2018). Index', Integrated Management (pp. 391-406). Emerald Publishing Limited. https://doi.org/10.1108/978-1-78714-561-020181021

Stern, M. J. (2018). Social science theory for environmental sustainability: A practical guide. Oxford University Press.

Thiele, L. P. (2016). Sustainability. John Wiley \& Sons.

Ugbaja, S. C. (2018). Management Practices Towards the Incorporation of Sustainability in African Universities. Management, 10(8). 